УДК: 7.033.2(497), 72.033

ББК: 85.113(3), 85.143(3)

A43

DOI: $10.18688 / \mathrm{aa} 199-2-28$

I. Jevtić

\title{
Painted Church Facades in Byzantine and "Post-Byzantine" Art and Their Aesthetics ${ }^{1}$
}

The archaeological material and the conservations reports provide evidence that many Byzantine churches were externally plastered and painted. But, since this top layer has disappeared in majority of the cases, usually only the fabric of the building is visible. Although many churches lost their colorful exterior surfaces, the question of painted facades (their original effect and meaning) needs to be taken into consideration in any thorough investigation of Byzantine church buildings and their decoration [7; 9, pp. 361, 381-382, 386-387, 406-407; 28, pp. 116-134; 28].

In her article, published in Zograf in 1976, Lydia Hadermann signaled that the exterior decoration represents a long and persistent tradition, and she supported this statement with relevant examples from different regions of the Byzantine Empire and its cultural sphere [13]. At the same time, Milka Čanak-Medić studied extensively the polychromy and painted facade decorations in the context of Late Antique and Byzantine architecture [4]. On the other hand, Maria Orlova examined the same phenomenon with a particular focus on figural representations [21]. Pursuing further these lines of research, Slobodan Curčić introduced the concept of painted facades as a universal principle in Byzantine architecture and stressed the necessity to re-examine the Byzantine architectural aesthetics in the light of such evidence [7; 9, pp. 361, 381-382, 386-387, 406-407]. Jelena Trkulja also analyzed the role of painted facades in forming a fuller understanding of Byzantine church exteriors, their aesthetic and symbolism, particularly in Late Byzantine architecture [28, pp. 116-134; 29]. Nevertheless, exterior facade paintings are not yet treated as an integral part of the decorative fabric of buildings, and they are seen usually as a regional phenomenon. In that sense, the fate of painted facades calls to mind the similar fate of polychrome architectural ceramic revetments, and together they may represent A Lost Art Rediscovered, to cite this evocative title given to a collection of related studies gathered by Sharon Gerstel and Julie Lauffenburger [12]. In both cases, we are confronted with our ignorance as well as the misconceptions about the original appearance of the Byzantine church buildings.

Contrary to the exterior architectural ceramic revetments, the painted facades seem to represent a more widespread and lasting phenomenon in the Byzantine world: they were not confined to certain regions only, nor were they limited to provinces and excluded from important

I would like to thank the organizers of the symposium for the invitation, the conference participants for their stimulating questions, and most particularly Anna Zakharova and Svetlana Maltseva for their generous hospitality. 


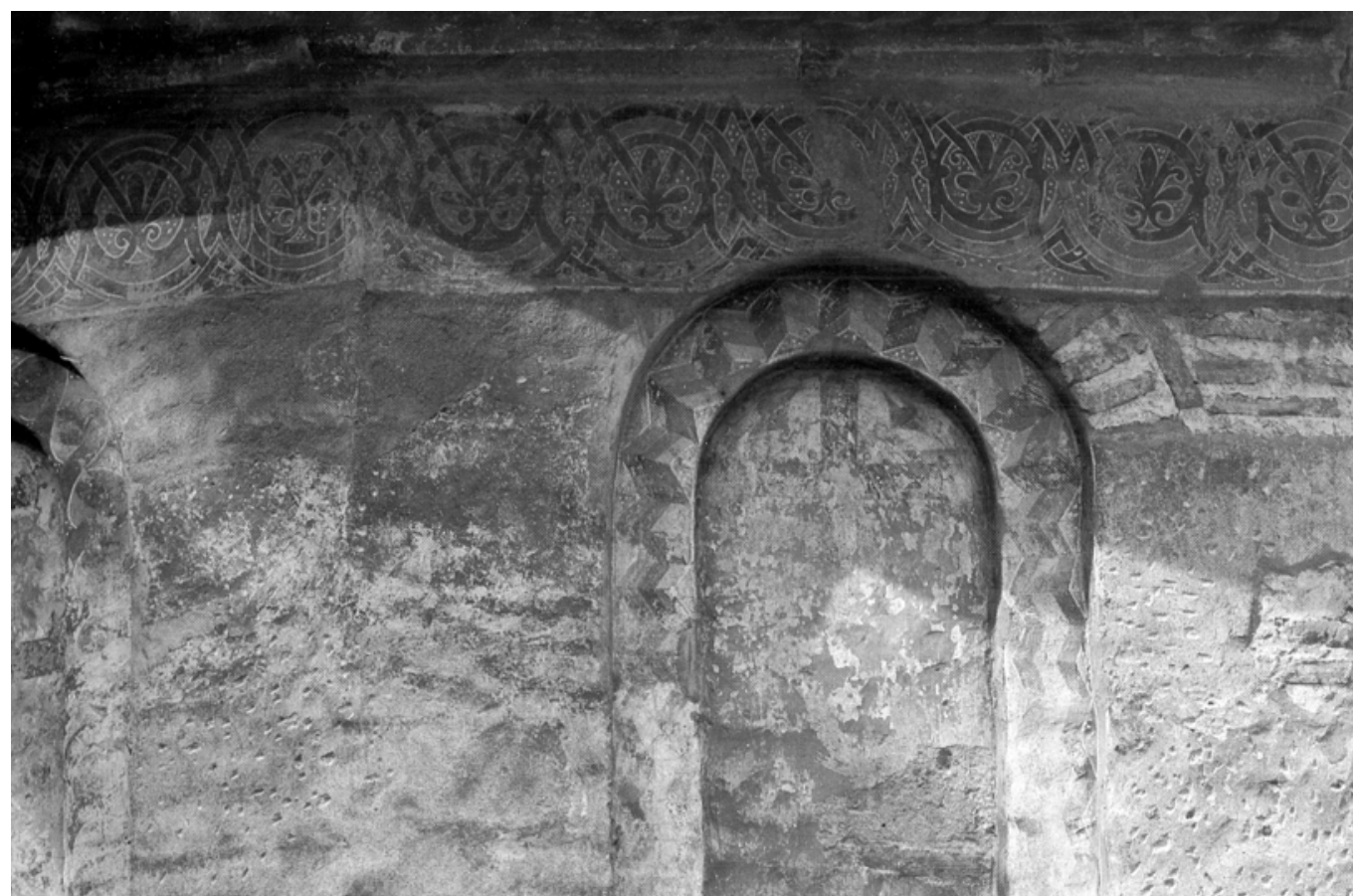

Fig. 1: The Myra Church. Drawing of the west wall. With the permission of Engin Akyürek

urban centers. They have not fallen out of use over the centuries, and painted facades become recurrent in Late Byzantine architecture only to flourish in Moldavian churches of the $16^{\text {th }}$ and $17^{\text {th }}$ centuries. With that state of the arts in mind, this article advances the question of how to approach the phenomenon of painted church exteriors. What would be the sources and meanings of that aesthetics and how should they be studied? Far from even attempting to give answers, the aim of this article is to bring this topic to the fore and raise questions about it. Therefore, I will first bring together some of the main aspects having a bearing on the subject, and then point to some problems and examples that call for further exploration.

The facade painting is an important issue for the scholarship on Byzantine architecture and art. But, the main problem is the fact that the archaeological evidence is scant and scattered. It depends on the chance of survival of a material that has a relatively short life span: the original plaster and paint on the exteriors have been either lost completely or renewed in centuries of use [7; 9, pp. 361, 381-382, 386-387, 406-407; 29].

Furthermore, we may perceive as surprising the possibility that beautiful brick and other ornaments embedded in the mural surfaces could have been some sort of "under drawing," plastered and repeated in paint [5]. In turn, imagining church exteriors covered with paintings does shift our perception of Byzantine architecture and its aesthetic into another dimension from the one that we are accustomed to seeing. It also opens questions about the very processes of the construction and decoration of buildings, the work organization of masons and painters and similar [9, pp. 361, 381-382, 386-387, 406-407; 29]. 


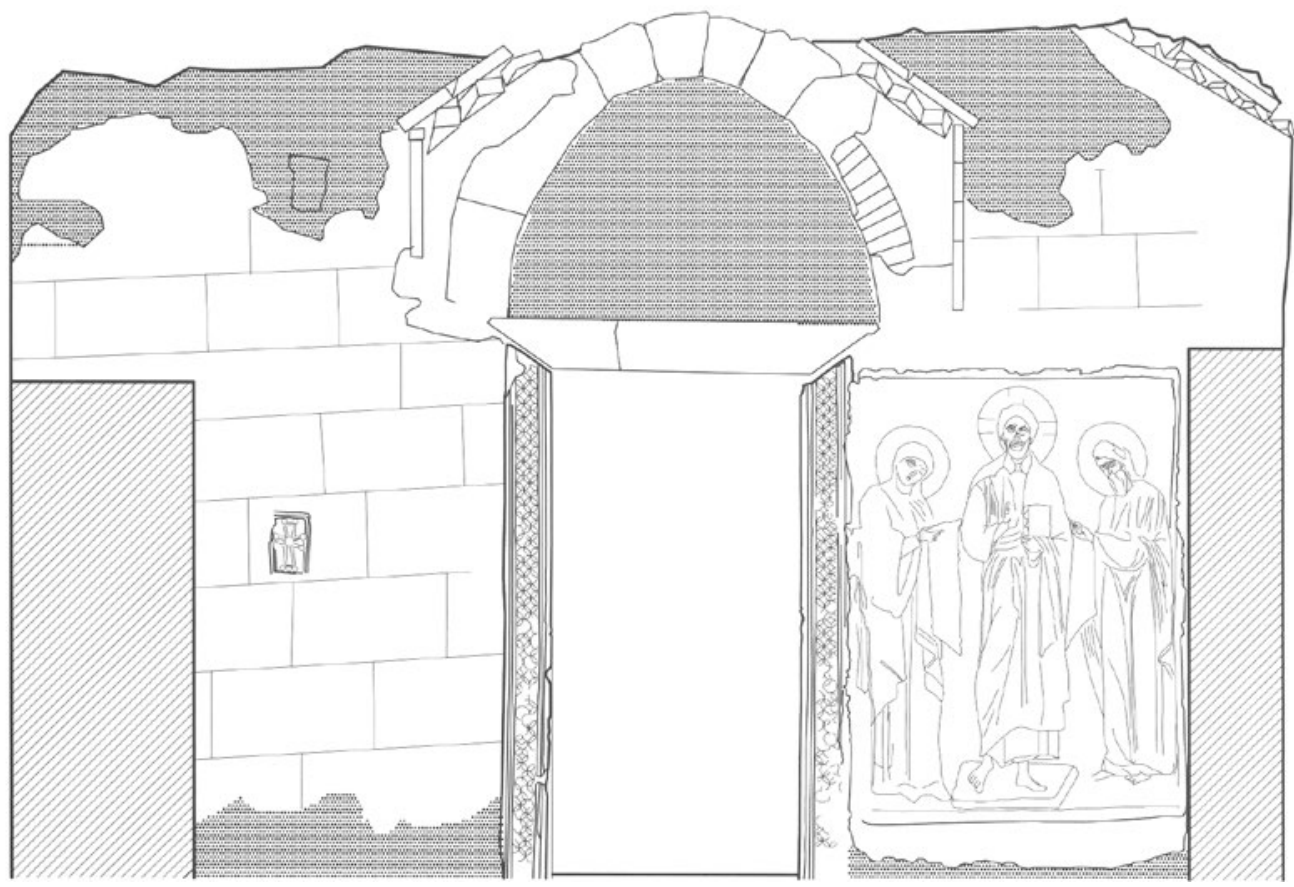

Fig. 2. Patriarchate of Peć. Church of the Virgin Hodegetria. After Đurić V. J., Ćirković S., Korać V. Pećka Patrijaršija. Belgrade, 1990 [10, fig. 63]

Finally, primary sources tell us little, if anything, about the effect that Byzantine church exteriors had on the observers [29]. How did people perceive and experience the church exteriors while viewing them within their daily environment is one of the questions that remain open. Collecting the data about the painted facades but also considering such data as a valid evidence for the revaluations of the church exteriors is certainly a way to start answering these questions.

The mosaic on the facade on the Old St. Peter's Basilica in Rome (440-461), representing Christ surrounded by the symbols of the evangelists and twenty-four old men of the Apocalypse, shows that the facade paintings may have deep roots in church exterior decorations [13; 28 , p. 128, nt. 327]. The remains of the figurative mosaics in the pediment of the $6^{\text {th }}$-century Basilica Euphrasiana in Poreč seem to confirm such assumption [13;26, pp. 5-6, fig. 198; 28, p. 128, nt. 327]. One can question whether the practice of the exterior painting, attested in Byzantium since the $10^{\text {th }}$ century, is in continuity with such earlier Christian tradition. However, the remaining evidence collected from several $11^{\text {th }}$ and $12^{\text {th }}$-century buildings indicates that many Middle Byzantine churches were externally plastered and painted. Few surviving fragments of painted plaster on the west façade of the $11^{\text {th }}$-century katholikon of Hosios Loukas Monastery suggest that the building, as originally built, was decorated with painted motifs that include, among other motifs, "pseudo-Kufic" letters [9, pp. 386-387; 28, p. 119]. Facades of the church of the Virgin Eleusa (1080) in the village of Veljusa were plastered and painted to imitate the building opus, done in brick [9, pp. 406-407; 28, pp. 120-121]. These and other buildings from the Middle but also Late Byzantine period included elaborate painted exte- 


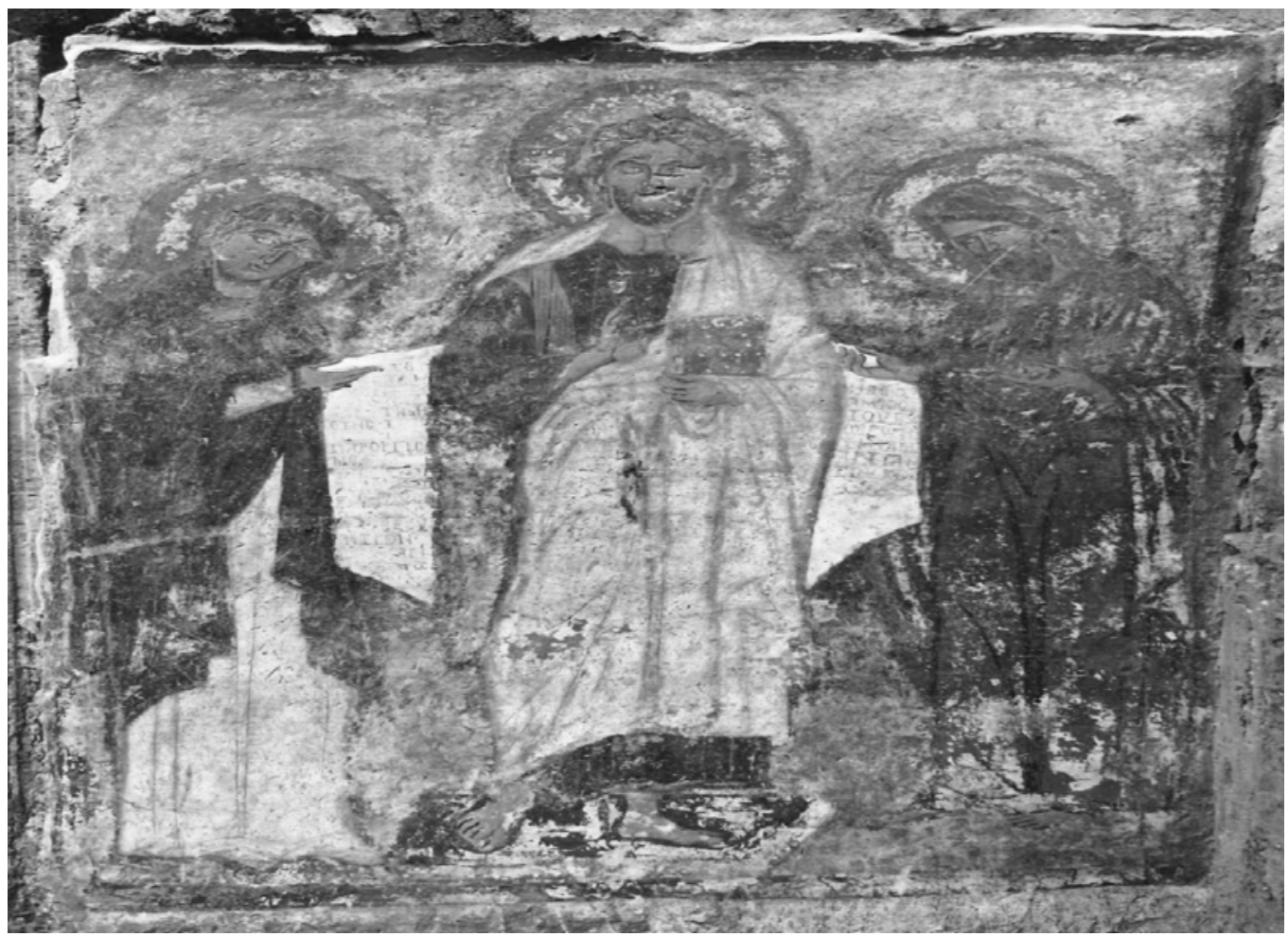

Fig. 3. The Myra Church. Deisis. With the permission of Engin Akyürek

rior decoration. For instance, facades embellished in painted imitation of building techniques were widespread in medieval Serbia as shown by the churches in the complex of the Patriarchate of Peć $\left(13^{\text {th }}\right.$ and $14^{\text {th }}$ centuries) (Fig. 2) [10].

Painted facades often consisted in various decorative patterns and lines imitating the building techniques but their repertoire could also feature figurative representations [21]. These could include the representations of the titular saints or protectors of the church, episodes from their lives, portraits of the donors, like in the Church of St. George in Kurbinovo (ca. 1191) or the Holy Anargyroi in Kastoria (end of the $12^{\text {th }}$ century) [9, pp. 381-382; $13 ; 28$, p. 121]. Western facade of the small $13^{\text {th }}$-century church from Myra, recently excavated in the area close to the ancient theatre, was decorated with the representation of the Deisis (Fig. 1 and 3) [1;2, pp. 86-88]. Lydia Hadermann has argued that, in such cases, the fresco decoration on the western facades repeats the symbolism and content of the narthex iconography [13]. Along that line, Sofia Kalopissi-Verti suggests that themes with eschatological and soteriological connotations depicted around the western portal, like the Deisis, represent another screen of intercessory images flanking a critical doorway [17]. Subjects on the exterior are identical to those found on the templon and the east wall of the narthex.

It is also worth signaling a group of seven churches in Kastoria, mostly from Late Byzantine period that are distinguished by the figurative representations on their eastern facades. 


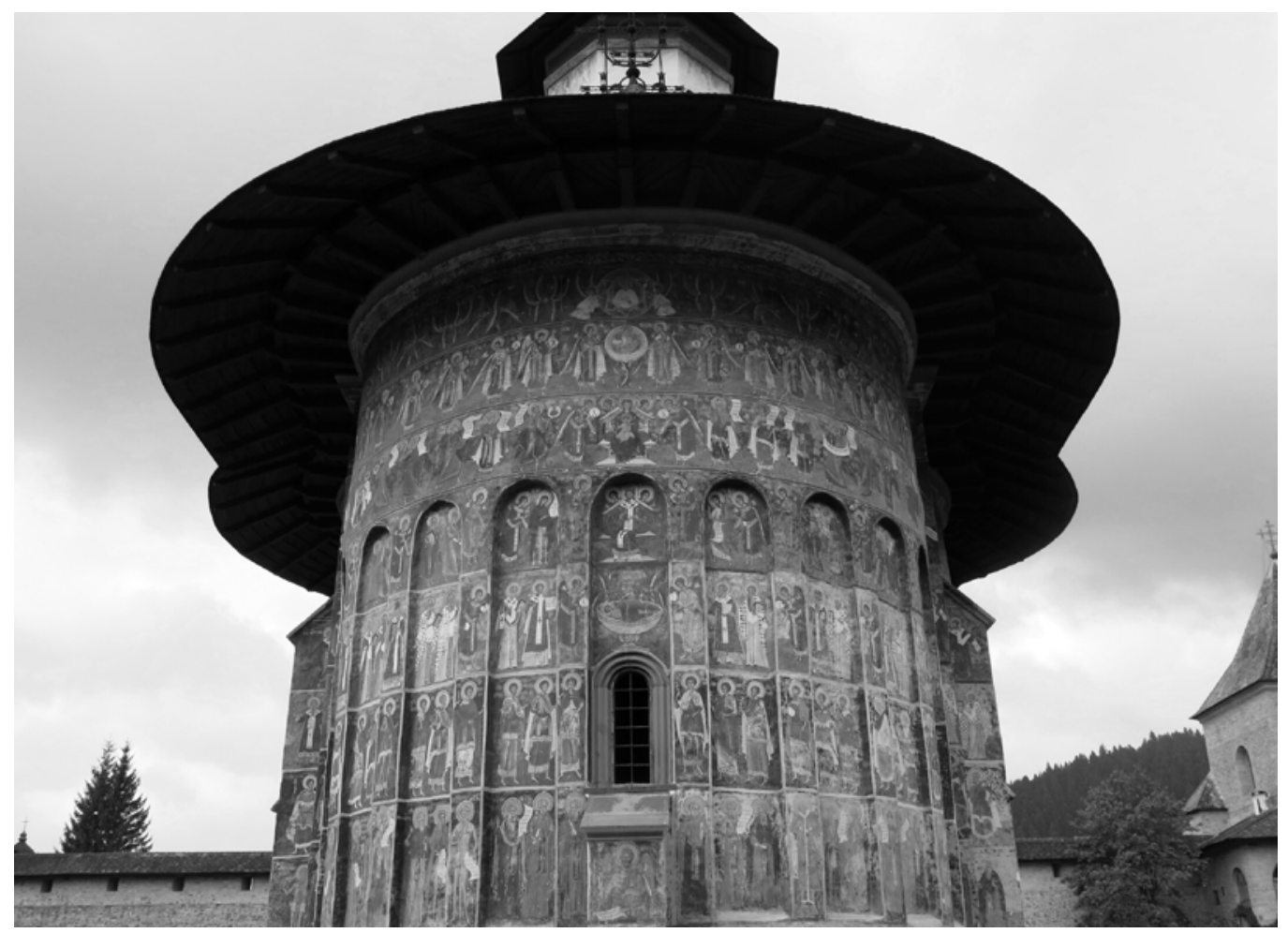

Fig. 4. Sucevița Monastery. Katholikon. View from the south-east side. Photo by I. Jevtić

Some of them, like the Church of St. Nicholas tou Kasnitzi, present the image of the patron saint, while the others, such as St. Nicholas tou Kyritzi, feature the Deisis, depicted on the eastern pediment of the church [24]. As both themes are frequently encountered on the western facades, their appearance on the eastern wall, i.e. the pediment, makes the examples from Kastoria rather exceptional though not unique. Similar cases of figurative images on the eastern facades were detected elsewhere in Northern Greece, but also in Serbia (Church in the monastery St. Prohor Pčinjski near Vranje) [27, pp. 318-319] or even in Georgia [24]. Nikos Siomkos explains the case of Kastoria by the ancient urban tissue of the town and the fact that the beholder was approaching these particular churches coming from the east and not the west side [24]. Thus, the author brings to the fore the role of the visual encounter between the beholder and the edifice in a dense urban context, where not only architectural but also painted decoration played its part.

As for the Constantinopolitan urban context and its churches, the facades of Christ Pantepoptes (1081-1087), known for their elaborate brick patterns and ornaments, were plastered and painted [22; 23, p. 179]. Ruy González de Clavijo, a Castilian traveler who visited Constantinople in 1403, provides another interesting testimony with his puzzling description of the eleventh-century church of St. Mary Peribleptos. His account mentions that "...the body of the church on the outside is completely decorated with pictures of different kinds, rich in gold and azure and many other colors..." and it may refer to images painted either in the 
narthex or in the exterior of the church, possibly at its entrance [6, pp. 31-32;19, p. 217] $]^{2}$. It is also worth signaling a portrait of Andronikos I that, according to the description of Niketas Choniates, the emperor set up on the Church of the Forty Martyrs in the center of Constantinople $[11]^{3}$. Unique in Byzantine art because of its unusual depiction of the emperor "dressed in the garb of a laborer," this image represents another valuable testimony of a painted panel, placed outside of the church. Thus, it provides important evidence about the public functioning of art, phenomenon whose implications have not been sufficiently investigated, as Anthony Eastmond had rightly pointed out [11]. It also opens up broader questions about viewing, reception and performativity of painted images and decoration placed in the exterior spaces.

Finally, the choice of themes and their depiction on particular parts of the exterior walls seem to indicate a tendency toward carefully elaborated inter-visual and symbolic connections between the church interior and exterior in Late Byzantine art [21; 28, pp. 167-209]. This trend reaches its peak in a group of monuments from Moldova that display grandly conceived painted exteriors. Here the artists extended and systematized the images into vast painted programs: their iconographic richness and the overall arrangement on the walls make the Moldavian churches a unique phenomenon in the Orthodox art. Certain images are particularly elaborated like the Last Judgement on the west facade of Voroneț (1547), the Tree of Jesse on the south wall and the Heavenly Ladder on the north wall of Sucevița (1601-1604) (Fig. 4) [18, pp. 191-199]. Finally, the artists did not only enlarge and extende the paintings to all facades of the church, but they also decorated the exterior of the apse: a practice previously unattested in the Byzantine world [14, p. 37; 15; 16]. By giving to the apse its specific character, artists develop in a unique way the liturgical aspect of the exterior decoration, supported by the inclusion of numerous inscriptions written in Old Slavonic [16].

To conclude, Late Byzantine architecture reveals a growing concern for the exterior decoration while long narrative cycles unfold in the interiors [8]. These two tendencies seem to meet and culminate in Moldavian churches where images enclose the building completely. Similar features can be observed in some Pontic churches, such as those in the monastery of the Virgin Sumela (1744) [20, pp. 144-146; 24]. Nicoletta Isar has rightfully observed that this phenomenon generates a semiotic break in the understanding of the architectural space: the exterior architectural surface becomes a painted surface, and programs from the interior spaces extend on the outside. Like a membrane, the wall now links and binds the inside and the outside [14, p. 37]. Images cover the building like a coat but a coat made of paint and color. Elisabeth Bolman coined the metaphor of "painted skins" while analyzing the interiors of Justinianic churches and trying to capture the essence of their opulent polychromatic decoration [3]. In the recent years, the role of color and light in the Early Byzantine aesthetics has been largely discussed. In turn, the polychromy and its relation to the architectural form, both in interior and exterior spaces, are issues that still await proper examination in Late Byzantine art and the Orthodox art produced during the Ottoman era. Coupled with the growing interest in painted inscriptions [25], for instance, it is time to re-think the role of painted decora-

2 I would like to thank Alex Rodriguez Suarez for his help with the text in Spanish and for a stimulating discussion about many confusing aspects in Clavijo's description.

$3 \quad$ I would also like to thank Andreas Rhoby for bringing this example to my attention. 
tions (whether painted images, ornaments or texts) in the adornment of exterior walls and the aesthetic impact such treatments had in the appearance of the buildings and on the beholders.

\section{References}

1. Aküyrek E. A Recently Discovered Thirteenth Century Church at Myra. Proceedings of the $17^{\text {th }}$ Symposium on Mediterranean Archaeology: SOMA 2013, Moscow, 25-27 April 2013. Oxford, Archaeopress Publ., 2015, pp. 14-23.

2. Aküyrek E. (ed.). Alakent Church: A Byzantine Monument at Myra (12 $2^{\text {th }}-13^{\text {th }}$ Centuries). Istanbul, Koç University Stavros Niarchos Center for Late Antique and Byzantine Studies Publ., 2019. 269 p.

3. Bolman E. Painted Skins: The Illusions and Realities of Architectural Polychromy, Sinai and Egypt. Approaching the Holy Mountain: Art and Liturgy at St. Catherine's Monastery in the Sinai. Turnhout, Brepols Publ., 2010, pp. 119-140.

4. Čanak-Medić M. Contribution à l'étude de l’origine de la polychromie sur les façades des édifices byzantins. Actes $d u X V^{e}$ congrès international détudes byzantines, Athènes, 1976, vol. 2. Athènes, Association Internationale des Etudes Byzantines Publ., 1981, pp. 107-120 (in French).

5. Ćirić J. The Art of Exterior Wall 'Decoration' in Late Byzantine Architecture. Mal'tseva S. V.; Staniukovich-Denisova E. Iu. (eds.). Actual Problems of Theory and History of Art: Collection of Articles, vol. 1 . St. Petersburg, NP-Print Publ., 2011, pp. 69-76.

6. Clavijo de R. G. Embajada a Tamorlán. Madrid, Editorial Castalia Publ., 1999. 432 p. (in Spanish).

7. Ćurčić S. Middle Byzantine Architecture on Cyprus: Provincial or Regional? Nicosia, Bank of Cyprus Cultural Foundation Publ., 2000. 38 p.

8. Curčić S. Religious Settings of the Late Byzantine Sphere. Byzantium Faith and Power (1261-1557). New York, Metropolitan Museum of Art Publ., 2004, pp. 65-77.

9. Curčić S. Architecture in the Balkans from Diocletian to Süleyman the Magnificent. New Haven, Yale University Press Publ., 2010. 913 p.

10. Đurić V. J.; Ćirković S.; Korać V. Pećka Patrijaršija. Belgrade, Jugoslovenska revija Publ., 1990, pp. 101-107 (in Serbian).

11. Eastmond A. An Intentional Error? Imperial Art and "Mis"-Interpretations under Andronikos I Komnenos. Art Bulletin, 1994, no. 76, pp. 502-510.

12. Gerstel E. J. S.; Lauffenburger J. A. (eds.). A Lost Art Rediscovered: The Architectural Cermics of Byzantium. Baltimore, Walters Art Museum; University Park, Pennsylvania State University Press Publ., 2001. 318 p.

13. Hadermann-Misguich L. Une longue tradition byzantine. La décoration extérieure des églises. Zograf, 1976, no. 7, pp. 5-10 (in French).

14. Isar N. Spatial Tropes of Iconicity: When Architecture Dissolves into Transparency. Proceedings of

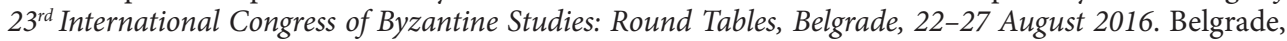
The Serbian National Committee of AIEB Publ., 2016. 1415 p.

15. Isar N. Le mur aboli: logique du dévoilement. Leiden, Alexandross Press Academic Publ., 2019. 220 p. (in French).

16. Isar N. Le mur aboli: le sacrement de la Parole dans les absides des églises moldaves. Byzantinoslavica, 1999, no. 60, pp. 611-632 (in French).

17. Kalopissi-Verti S. The Proskynetaria of the Templon and Narthex: Form, Imagery, Spatial Connections and Reception. Threshold of the Sacred: Architectural, Art Historical, Liturgical, and Theological Perspectives on Religious Screens, East and West. Washington DC, Dumbarton Oaks Research Library and Collection Publ., 2006, pp. 107-132.

18. Mango C. Byzantine Architecture. Milan, Electra Editrice Publ.; New York, Rizzoli Publ., 1985. 215 p.

19. Mango C. The Art of the Byzantine Empire, 312-1453: Sources and Documents. Toronto, Toronto University Press Publ., 1986. 272 p.

20. Millet G.; Talbot Rice D. Byzantine Painting at Trebizond. London, G. Allen \& Unwin Publ., 1936. 182 p.

21. Orlova M. A. Naruzhnye rospisi srednevekovykh pamiatnikov arkhitektury. Vizantiia. Balkany. Drevniaia Rus' (External Paintings of Mediaeval Buildings. Byzantium, Balkans, Old Rus). Moscow, Nauka Publ., 1990. 240 p. (in Russian).

22. Ousterhout R. Some Notes on the Construction of Christos Ho Pantepoptes (Eski Imaret Camii) in Istanbul. Deltion tis Christianikis Archaiologikis Etaireias, 1991-1992, vol. 16, pp. 47-56. 
23. Ousterhout R. Master Builders of Byzantium. Princeton, Princeton University Press Publ., 1999. 320 p.

24. Siomkos N. Fresques sur la façade orientale des églises à Kastoria. Une pratique byzantine inconnue. Afieroma ston akadimaiko Panagioti L. Vokotopoulo. Athens, Kapon Publ., 2015, pp. 465-471 (in French).

25. Subotić G.; Miljković B.; Špadijer I.; Toth I. Natpisi istorijske sadržine u zidnom slikarstvu. Tom Prvi. XII-XIII vek (Inscriptions with Historical Contents in Monumental Painting, vol. 1. $12^{\text {th }}-13^{\text {th }}$ Century). Belgrade, Srpska Akademija Nauke i Umetnosti Publ., 2015. 142 p. (in Serbian).

26. Terry A.; Maguire H. Dynamic Splendor: The Wall Mosaics in the Cathedral of Eufrasius at Poreč. University Park, Pennsylvania State University Press Publ., 2007. 416 p.

27. Todić B. Srpsko slikarstvo u doba kralja Milutina (Serbian Painting in the Time of King Milutin). Belgrade, Draganić Publ., 1998. 395 p. (in Serbian).

28. Trkulja J. Aesthetics and Symbolism of Late Byzantine Church Facades, 1204-1453, Ph. D. Diss. Princeton University, 2004.

29. Trkulja J. Divine Revelation Performed: Symbolical and Spatial Aspects in the Decoration of Byzantine Churches. Spatial Icons: Performativity in Byzantium and Medieval Russia. Moscow, Indrik Publ., 2011, pp. 213-246.

Title. Painted Church Facades in Byzantine and Post-Byzantine Art and Their Aesthetics.

Author. Ivana Jevtić - Ph. D., assistant professor. Koç University, Rumelifeneri Yolu, 34450 Sarıer, Istanbul, Turkey. ijevtic@ku.edu.tr

Abstract. Although painted church facades represent long tradition, attested in different regions of the Byzantine world, they have not been recognized as a widespread phenomenon. Scholars, like Slobodan Curčić, stressed the necessity to re-examine Byzantine architectural aesthetics in the light of such evidence. Nevertheless, exterior paintings are not yet treated as an integral part of the decorative fabric of buildings. The main problem lies certainly in the scarcity and fragility of the archaeological data that needs to be recorded and collected more systematically.

The aim of this article is to draw attention to this issue, most particularly for the Late and Post-Byzantine periods. It discusses several relevant examples of painted facades, the choice of depicted motives (both ornamental and figurative) and their display on particular parts of the building with intention to question the sources and meanings of that artistic practice. Spurred by the growing interest in non-textual aspects of painted inscriptions, this article reconsiders the place of painted decorations in the adornment of exterior walls and the impact such aesthetic had on the appearance of Byzantine churches and their beholders.

Keywords: Byzantine architecture; church facades; exterior painted decoration; Balkans; Constantinople; Late Byzantine art; Post-Byzantine art.

Название статьи. Наружные росписи византийских и поствизантийских храмов и их эстетика.

Сведения об авторе. Евтич Ивана - Ph. D., доцент. Университет Коч, Румелифенери Йолу, 34450 Сарыер, Стамбул, Турция. ijevtic@ku.edu.tr

Аннотация. Хотя наружные росписи представляют собой длительную и устойчивую традицию, засвидетельствованную в различных регионах Византийской империи и странах византийского круга, такая декорация фасадов церквей не считалась широко распространённым явлением. Исследователи, например Слободан Чурчич, подчеркивали необходимость пересмотра эстетики византийской архитектуры в этом аспекте. Тем не менее наружные росписи до сих пор не рассматривались как неотъемлемая составляющая декора здания. Главная проблема, несомненно, заключается в скудости и фрагментарности археологических данных, которые необходимо фиксировать и собирать систематически.

Цель данной статьи - привлечь внимание к тому, что фасадные росписи являются важной проблемой для изучения архитектуры, особенно поздневизантийского и поствизантийского периодов. Рассмотрено несколько примеров таких расписных фасадов, разбирается набор декоративных мотивов (орнаментальных и фигуративных) и их размещение на отдельных частях здания, для того чтобы понять, каковы источники этой практики и в чем её эстетический смысл. В этой статье, инспирированной растущим интересом к надписям в монументальной живописи, во многом пересматривается место фресковой декорации в украшении стен, а также влияние данной практики на внешний облик византийских церквей и их восприятие зрителями.

Ключевые слова: византийская архитектура; фасады церквей; наружные росписи; Балканы; Константинополь; поздневизантийское искусство; поствизантийское искусство. 